\title{
NŐK A PÉNZINTÉZETI SZFÉRA VEZETÉSÉBEN
}

\author{
(Women in the management of financial business)
}

\author{
BIHARI ZSUZSANNA
}

Magyarországon 1948-tól 1986-ig egyszintuí bankrendszer mứködött, a pénzintézeti szolgáltatásokat pedig egyfajta munkamegosztási rendszerben látták el: az MNB a közületek és közintézmények számláit vezette, finanszírozta múködésüket, az OTP fí́kjai a városok és az 5000 fổnél nagyobb lélekszámú községek lakosságának pénzügyi szolgáltató intézményei voltak, ezen túlmenóen a kedvezményes, állami támogatású konstrukciókat múködtették, a takarékszövetkezetek az OTP tevékenységétốl eltéró profillal községekben nyújtottak lakossági szolgáltatásokat. Szakosított pénzintézetek létrehozásával csökkentették az MNB feladatát és hatáskörét ${ }^{1}$, az OTP tevékenységi körét 1971-tôl kibõvítették a tanácsok és tanácsi szervek számláinak vezetésével, és kisvállalkozások finanszírozásának jogát is megkapták. A takarékszövetkezetek 1976-tól külön engedély alapján városokban is kifejthették tevékenységüket, 1987-tốl pedig már megyeszékhelyeken is jelen lehetnek.

1987. január 1-ével kétszintũvé vált a bankrendszerünk. A bankrendszer reformja során létrehoztak öt kereskedelmi bankot (MHB, OKHB, MKB, BB, ÁÉB), melyek között felosztották az ügyfélkört (vállalatokat és intézményeket), az MNB fiókhálózatát (és a személyzetének egy részét).

A kereskedelmi bankok megteremtése vákuumot hozott létre a munkaerổpiacon. Egy korábban meglehetốsen zárt és tekintélyes, de anyagilag kevéssé megbecsült szakma konjunktúráját eredményezte. A piaci viszonyok kiépítése felé araszoló gazdaságunkban a banktevékenység megkövetelte a mintaképül szolgáló országokban már kivívott tekintélyt és megbecsültséget. Ettól kezdve már kifizetôdó vállalkozás lett bankárnak lenni. A legnagyobb problémát az jelentette, hogy a gazdálkodásnak és a pénzintézeti tevékenységnek egy egészen új metódusa kezdôdött, amelynek hiányzott a szakembergárdája. Széles körben nem létezett sem vezetối, sem napi gyakorlati szinten ez a tudás. Emiatt a kereskedelmi bankok sürgốs munkaerốigényüket elsốsorban a banki vagy pénzügyi gyakorlattal rendelkezốk körébốl elégítették ki. Ahogy többen fogalmaztak: olyan emberekre volt szükségük, akinek fogalma volt a bizonylati rendról és pénzügyi fegyelemrốl, vagyis olyan munkaerổre, amely elsốsorban az MNB fiókjaiban és a cégek pénzügyi alkalmazottjaként edzódött. Az ily módon szóba kerülốk között pedig közismerten a nók voltak többségben.

Napjainkra lezáródott e terület fejlổdésének elsố szakasza, a nagybankok kiépítették fiókhálózatukat, újabb kereskedelmi bankok jöttek létre. Minket elsốsorban az érdekel, hogy milyen folyamatok zajlottak le ez alatt a néhány év alatt a munkaerổpiac e szegmensének vezetổi pozícióiban. Tudjuk, hogy a nagybankok vezérkara az MNB felsố- és középvezetổi közül került ki, de a banki szféra konjunktúrája által teremtett szakemberhiány más területekrôl érkezóknek 
is gyors felemelkedési lehetőséget biztosított. Az újonnan alakuló bankok vezetésüket ,,agyelszívás" útján igyekeztek megszerezni, ami jelentôs mértékben felhajtotta a béreket. Feltételezzük, hogy ez esetben a szakirodalomban részletesen leírt konjunkturális kontraszelekciós mechanizmus érvényesül. Ennek lényege, hogy a munkaerổpiac felfutó szegmensei, melyek magasabb bérekkel és presztízzsel járnak, általában az előnyösebb kiinduló piaci pozíciókkal rendelkezók

számára érhetốk el. Különbözõ kutatások tanulsága szerint ezen a téren a férfiak tradicionálisan igen nagy elổnyökkel indulnak (Barron-Norris 1976; Crompton-Jones 1984; Koncz 1987; Nagy 1992). A pénzügyi szféra magyarországi érdekessége, hogy a korábbi szerény javadalmazás a férfiakat tisztes távolban tartotta e területtốl. Ez egyben azt jelenti, hogy a szakma piaci pozíciójának változása és presztízsének növekedése az e területen dolgozók pozícióját felértékelte; egyedülálló módon, egy nốtöbbségứ szférában.

Nem tudni pontosan, mi történt az elmúlt évek során, mindenesetre tanulságos a BKE Szociológia tanszékén 1991-ben végzett ,Gazdasági elit” kutatás tapasztalata, amely szerint a vezetớk - a magánosoktól eltekintve - a banki szférában tudnak a legmagasabb jövedelmekre szert tenni. A nổi fizetések is ezen a területen a legmagasabbak, ugyanakkor itt maradnak el leginkább a férfiakétól (Nagy 1992).

Eme jelenség további vizsgálata felé tett tájékozódó lépést jelentett a kérdốíves kutatás, melyet a BKE Szociológiai tanszékének támogatásával készítettem 1992 első negyedévében. Ezen kutatás eredményeit foglalja össze ez a dolgozat, amely nem születhetett volna meg Nagy Beáta és Lengyel György segítsége nélkül. Ezúton mondok köszönetet támogatásukért, ötleteikért és bíráló megjegyzéseikért.

A felmérést vidéki takarékszövetkezetek és bankfiókok vezetôi körében végeztem. A mintavétel a , Magyar pénzügyi és tôzzsdei almanach 1991" adataiból rétegzett mintavétel segítségével történt. ${ }^{2}$ (Az Almanach adatai 1991. augusztusi állapotot mutatnak.)

Négy megye és Budapest kivételével a kérdôiveket postán továbbítottam, Baranya, Csongrád, Gyốr-Sopron és Szabolcs-Szatmár-Bereg megyében és a fôvárosban telefonon történô egyeztetés után a kérdốívek kitöltésére vállakozókat személyesen kerestem fel. Összesen 59 kérdőívet kaptam vissza postán, ebból 54 volt feldolgozható. Levélben nagyobb arányban küldték vissza a kérdốiveket nốk, ezzel szemben több férfi vállalkozott a személyes találkozásra (l. táblázat). Ezúton szeretném megköszönni valamennyi banki és takarékszövetkezeti vezetố segítségét, akiknek a válaszai és adatai nélkül nem készülhetett volna el a dolgozat.

A kitöltött kérdő́ivek a takarékszövetkezetek és a budapesti bankfiókok vezetỏire nézve reprezentatívek. Az alapadatok bizonytalanságai, valamint a kis minta miatt az eredmények nem alkalmasak a pénzintézetek fiókjainak vezetơire vonatkozó általános jellemzốk megállapítására; csak problémák, tájékozódási pontok és hipotézisek megfogalmazása lehetséges. 
Tér és Társadalom, 7. 1993. 1-2. 69-88. p.

1. TÁBLÁZAT

Az alapadatok: a minta és a kitöltött kérdőivek megoszlása

(Basic data: distribution of samples and questionnaires)

\begin{tabular}{l|c|c|c}
\hline & Bankfiókok & Takarékszövetkezetek & Összesen \\
\hline \multicolumn{4}{|c}{ Alapadatok } \\
\hline Férfi & 235 & 132 & 367 \\
\hline Nó & 160 & 128 & 288 \\
\hline Ismeretlen & 93 & 0 & 93 \\
\hline Összesen & 488 & 260 & 748 \\
\hline \multicolumn{4}{|c|}{ Minta } \\
\hline Férfi & 72 & 44 & 116 \\
\hline Nó & 48 & 39 & 87 \\
\hline Ismeretlen & 26 & 0 & 26 \\
\hline Összesen & 146 & 83 & 54 \\
\hline \multicolumn{4}{|c|}{ Beérkezett kérdôivek } \\
\hline Férfi & 33 & 21 & 54 \\
\hline Nó & 33 & 21 & 108 \\
\hline$\ddot{O}$ sszesen & 66 & 42 & \\
\hline
\end{tabular}

Forrás: Magyar Pénzügyi és Tôzsdei Almanach 1991, kérdốives felmérés 1993.

\section{Nók a pénzintézeti szféra vezetésében}

A nem anyagi szektorra vonatkozó adatok a KSH kiadványai alapján nem követhetốk nyomon, így a pénzintézeti szférára vonatkozóan a 10 legnagyobb kereskedelmi bankot és az MNB-t megkeresve igyekeztünk olyan adatokhoz jutni, amelyek kellốképp reprezentálják az ott dolgozókat. Hét bank szolgáltatott adatokat különféle mélységú bontásban.

A vizsgált körben a banki alkalmazottak $82 \%$-a nô, azaz a bankszakmát tipikusan elnôiesedett szakmának tekinthetjük. A dolgozók 3/4-e középiskolai végzettséggel rendelkezikés elsôsorban rutinjellegũ adminisztratív munkát végez. A felsôfokú végzettségủek aránya $16,8 \%$. A nốk alulreprezentáltak mind az alapfokú, mind a felsôfokú végzettségũek között, ezzel szemben felülreprezentáltak a középiskolát végzettek között. Létszámarányukból eredōen a nốk minden iskolai végzettségi szinten többségben vannak (2. táblázat). 


\section{TÁBLÁZAT}

A banki alkalmazottak nemenként és iskolai végzettség szerint (Number of bankclerks by gender and education)

\begin{tabular}{|c|c|c|c|c|c|c|}
\hline \multicolumn{7}{|c|}{ ALKALMAZOTTAK } \\
\hline \multirow{3}{*}{ Megnevezés } & \multirow{3}{*}{$\begin{array}{c}\text { Férfi } \\
\text { fố }\end{array}$} & \multirow{3}{*}{$\frac{\text { Nó }}{\text { fó }}$} & \multirow{3}{*}{$\frac{\text { Együtt }}{\text { fố }}$} & \multirow{3}{*}{$\begin{array}{c}\text { Nơk aránya } \\
\%\end{array}$} & Nốk & Férfiak \\
\hline & & & & & \multicolumn{2}{|c|}{ megoszlása } \\
\hline & & & & & $\%$ & $\%$ \\
\hline Létszám & *4536 & ${ }^{*} 20973$ & 25509 & 82,2 & & \\
\hline Iskolai végzettség & $* * 3546$ & $* * 17296$ & 20842 & 82,9 & 100,0 & 100,0 \\
\hline alapfokú & 320 & 1103 & 1423 & 77,5 & 6,4 & 9,0 \\
\hline középfokú & 1772 & 14140 & 15912 & 88,9 & 81,8 & 50,0 \\
\hline felsôfokú & 1454 & 2053 & 3507 & 58,5 & 11,9 & 41,0 \\
\hline
\end{tabular}

*7 bank adata

**6 bank adata

Forrás: Bankok önkéntes adatszolgáltatása 1992.

A bankok vezetésében a nốk létszámarányukhoz képest alulreprezentáltak, de a részvételük ennek ellenére igen jelentôs. Arányuk $62,2 \%$, amely az országos átlag majdnem kétszeresét jelenti (3. táblázat) ${ }^{3}$.

\section{TÁBLÁZAT}

A banki vezetók száma és megoszlása nemenként és iskolai végzettség szerint ${ }^{4}$ (Number and distribution of bank managers by gender and education)

\begin{tabular}{|c|c|c|c|c|c|c|}
\hline \multicolumn{7}{|c|}{ VEZETÓK } \\
\hline \multirow{3}{*}{ Megnevezés } & \multirow{3}{*}{$\begin{array}{c}\text { Férfi } \\
f o ̈ \\
\end{array}$} & \multirow{3}{*}{$\begin{array}{l}N o \tilde{} \\
f \tilde{r} \\
\end{array}$} & \multirow{3}{*}{$\frac{\text { Együtt }}{\text { fó }}$} & \multirow{3}{*}{$\begin{array}{c}\text { Nók aránya } \\
\%\end{array}$} & Nôk & Férfiak \\
\hline & & & & & \multicolumn{2}{|c|}{ megoszlása } \\
\hline & & & & & $\%$ & $\%$ \\
\hline Létszám & ${ }^{*} 1207$ & *1984 & 3191 & 62,2 & & \\
\hline Iskolai végzettség & $* * 1139$ & $* * 1910$ & 3049 & 62,6 & 100,0 & 100,0 \\
\hline középfokú & 327 & 1019 & 1346 & 75,7 & 53,4 & 28,7 \\
\hline felsôfokú & 812 & 891 & 1703 & 52,3 & 46,7 & 71,3 \\
\hline
\end{tabular}

\footnotetext{
*6 bank adata
}

**3 bank adata

Forrás: Bankok önkéntes adatszolgáltatása 1992. 
Az 1991-es Magyar Pénzügyi és Tő̉zsdei Almanach adatai szerint 40 hazai érdekeltségú bank €lsố számú vezetổje közül 4 volt nố. A legfelsổ vezetốk közötti 10\%-os jelképes részvétel mellett a bankfiókvezetôk $40,5 \%$-a, a takarékszövetkezeti vezetốk 49,2\%-a nố (l. táblázat).

Ezen adatok ismeretében nyitott kérdés formájában kérdeztük meg a felkeresett takarékszövetkezeti és bankfiókvezetốket, hogy véleményük szerint miért van viszonylag sok nố a bankszakma vezetésében. Több ok megnevezésére is lehetôség volt, és a kapott válaszok jól elkülöníthetô típusokra bonthatók (4. táblázat).

\section{TÁBLÁZAT}

Miért van viszonylag sok nố a bankszakma vezetésében? (Why are there relatively many women in bank management?)

\begin{tabular}{l|c|c|c|c|c}
\hline & $\begin{array}{l}\text { Tak.szö- } \\
\text { vetkezet }\end{array}$ & Bankfiók & \multicolumn{3}{|c}{ Összesen } \\
\cline { 2 - 7 } & Együtt & Együtt & Férfi & Nổ & Együtt \\
\hline a munka jellege miatt (pontosság, kötöttségek) & 11 & 27 & 16 & 22 & 38 \\
\hline elnóiesedett pálya & 6 & 12 & 11 & 7 & 18 \\
\hline $\begin{array}{l}\text { alacsony presztízs, alacsony bér miatt kevés } \\
\text { férfi volt }\end{array}$ & 8 & 9 & 12 & 5 & 17 \\
\hline a nók jobban tudnak bánni az ügyfelekkel & 2 & 3 & 2 & 3 & 5 \\
\hline nók számára jó karrierlehetôség & 1 & 3 & 2 & 2 & 4 \\
\hline egyéb & & 4 & 2 & 2 & 4 \\
\hline
\end{tabular}

Forrás: Kérdôives felmérés, 1992.

A kérdésben megfogalmazott megállapítás többek számára az újdonság erejével hatott. A megkérdezettek közül legtöbben a végzendổ munka jellegét jelölték meg a jelenség okaként. \$zerintük a nốk a precizitást, pontosságot igénylố munkát eredményesebben végzik. Ezzel összefüggésben említették, hogy a nốk jobban bírják a papírhalmokhoz, számoszlopokhoz és az íróasztalhoz kötöttséget, szívesebben és nagyobb türelemmel végzik az ilyen munkákat, mint a férfiak. Ennél sokkal kisebb számban említették a pálya elnóiesedett voltát, valamint a közelmúltban jellemzỏ alacsony erkölcsi és anyagi megbecsültségét.

A takarékszövetkezeti vezetốk közül többen említették, hogy ezek az intézmények a falvakban a személyes ismeretség és bizalom alapján, , ,családszerúen' mứködtek. Véleményük szetint a nốk a családban betöltött kommunikatív, összetartó és szervezó szerepük folytán alkalmasak a takarékszövetkezeteknél végzendổ feladatra, $s$ szívesen vállalják is azt. Többen úgy yélték, hogy emiatt a nốk az ügyfélkörrel való kapcsolattartásban sikeresebbek a férfiaknál. (Megjegyzendô, hogy ezt az érvrendszert csak férfi vezetớk hangoztatták, nốkben nem fogalmazódott meg ehhez hasonlatos vélemény.)

A férfiak és a nốk véleménye között jelentốs eltérések vannak. A nốk egyértelmũen a munka jellegét tartják a legfontosabb tényezốnek, minden más magyarázat ereje eltörpül emellett. 
A férfiak szerint ez sokkal kevésbé súlyos tényezô, ốk viszont a nốknél lényegesen fontosabbnak ítélik a pálya meg nem fizetettségét és elnőiesedését. Az álláspontok különbségének magyarázata a nốk és a férfiak pályafutásának eltérésében kereshetô. A késốbbiekben részletesen elemzendô karrierek egyik legfontosabb jellegzetessége az, hogy a nốk igen nagy hányada belülrốl ,,nevelt" vezetổ, azaz a hierarchiát végigjárva került a vezetôk közé. A nôk munkatapasztalatai és a vezetésbe való bekerülésük módja szemükben felerôsíti a végzett munka jelentổségét. A férfiak viszont szinte csak vezetônek lépnek be eme szakmába, ezért tapasztalataik a munka jellegével kapcsolatban kevésbé meghatározók. A férfiak családfenntartó, ma inkább fổ keresổ szerepük következtében az alacsony bér jelentôségét lényegesen magasabbra értékelték, mint a nók.

A különféle vezetôi szinteket vizsgálva a jól ismert képet kapjuk: az alsó vezetôk $71 \%$-a, a középvezetốk $56 \%$-a, a felsővezetôk $39 \%$-a nô. A nổi vezetốk $2 / 3$-a tehát a vezetési hierarchia alján, 27\%-a a középvezetésben dolgozik, és mindössze 6,3\%-ukat találjuk a felsốvezetôk között. Ezzel szemben a férfiak $41 \%$-a alsó vezető, $30 \%$-a középvezetổ és $14 \%$-a felsôvezetô. Így indokolt a kijelentés: a nôk tipikusan a vezetési hierarchia alsóbb régióiban töltenek be funkciót (5. táblázat).

\section{TÁBLÁZAT}

Bankok vezetési hierarchiäja nemenként és iskolai végzettség szerint (Hierarchy of bank management by gender and education)

\begin{tabular}{|c|c|c|c|c|c|c|c|c|c|}
\hline \multirow{3}{*}{ Megnevezés } & \multicolumn{3}{|c|}{ ALSÓ VEZETỖK } & \multicolumn{3}{|c|}{ KÖZÉPVEZETÕK } & \multicolumn{3}{|c|}{ FELSỐ VEZETŐK } \\
\hline & Férfi & Nô & $\begin{array}{c}\text { Nốk } \\
\text { aránya }\end{array}$ & Férfi & Nô & $\begin{array}{c}\text { Nốk } \\
\text { aránya }\end{array}$ & Férfi & Nố & $\begin{array}{c}\text { Nõk } \\
\text { aránya }\end{array}$ \\
\hline & fơ & fổ & $\%$ & fỏ & fổ & $\%$ & fö & fổ & $\%$ \\
\hline Létszám* & 464 & 1127 & 70,8 & 364 & 464 & 56,0 & 169 & 107 & 38,8 \\
\hline Iskolai végzettség** & 80 & 292 & 78,5 & 169 & 273 & 61,8 & 69 & 60 & 46,5 \\
\hline középfokú & 27 & 210 & 88,6 & 17 & 93 & 84,6 & 3 & 3 & 50,0 \\
\hline felsôfokú & 53 & 82 & 60,7 & 152 & 180 & 54,2 & 66 & 57 & 46,3 \\
\hline
\end{tabular}

A nốk számottevố hátrányait látva indokolt megvizsgálni, hogy érvényesül-e valamiféle diszkrimináció a nốkkel szemben a banki vezetésben. Az adatgyújtés során mindenütt tiltakoztak a diszkrimináció létét firtató kérdés hallatán. Úgy gondolják, hogy a nôk nem szenvednek hátrányos megkülönböztetést a munkahelyeken, nagyon sok nô van a vezetésben, sổt több mint ezt megelổzôen. Azt többen is elképzelhetőnek tartották, hogy a döntési pozícióban lévốk némi elổitélettel viseltetnek a vezetối ambíciókkal rendelkezô nốk iránt, de ennek igen kevés jelentốséget tulajdonítottak. 
A rendelkezésre álló adatokból csak az iskolai végzettség és vezetési hierarchiában elfoglalt pozíció alapján lehet következtetéseket levonni. Sajnos a vezetési csoportonként, nemek szerinti bontásban rendelkezésre álló iskolai végzettségi adatok nem alkalmasak elemzésre, de egyéb adatok összevetésébôl megfogalmazhatunk hipotéziseket.

A vezetốk 55,9\%-ának felsôfokú végzettsége van, ezen belül a vezetổ nốk $47 \%$-a, a férfiak 71\%-a rendelkezik felsôfokú végzettséggel. Ebból következően a nók között magasabb a középiskolai végzettséggel rendelkezók aránya (3., 5. táblázat). A férfiaknak $26,6 \%$-a, a nốknek 9,5\%-a vezetô.

A nốk iskolai végzettségi szintje alacsonyabb a férfiakénál, így ez részben indokolja a nốk vezetésben való alacsonyabb részvételét. Az iskolai végzettséget figyelembe véve azonban azt tapasztalhatjuk, hogy a középiskolai végzettségú férfiaknak $18,5 \%$-a, a nốknek csak 7,2\%-a kerül be a vezetésbe, míg a felsôfokú végzettségư férfiak 55,8\%-a, a nốk 43,4\%-a tagja a vezetésnek. Ez azt jelenti, hogy a középiskolai végzettségư férfiak két és félszer gyakrabban kerülnek be a vezetésbe, mint az ugyanolyan végzettségû̉ nôk. Egyetemet, fổiskolát végezve javulnak a nốk esélyei, így csak 1,28-szor jobb a férfiak bekerülési rátája. Összességében a férfiaknak háromszor annyi esélyük van a vezetốk közé bekerülni, mint nố kollégáiknak. Vagyis a vezetôkiválasztásban olyan erốk munkálkodnak, amelyek a nốk számára kevesebb esélyt adnak.

\section{Bankfiók- és takarékszövetkezeti vezetók}

Elöljáróban meg kell jegyezni, hogy a takarékszövetkezetek és bankfiókok elkülönülnek egymástól, e kétféle pénzintézet eltérô funkciójából és múködési területébốl adódóan. A takarékszövetkezetek továbbra is a községek lakosságának betétgyưijtô ,,bankjai”, a bankfiókok pedig a városi lakosság és a gazdál kodó szervezetek pénzügyi szolgáltató intézményei. Mióta városokban is találhatók takarékszövetkezetek, azóta emelkedett a szolgáltatásaik és a foglalkoztatott nunkaerổ képzettségi színvonala, de a felmérés tanulsága szerint nagyon korlátozott és áttételes ạz átjárás a kétféle pénzintézet között. További különbséget jelent, hogy a banki munkaerốpiac felfutása ellenére a takarékszövetkezetektốl nem történt számottevô átáramlás a bankokhoz. Ez természetesen az intézmények területi elkülönülésével, ezen túl a munkaerô rekrutációs körének különbségével is magyarázható.

Ebben a felmérésben 108 vezetốrốl van szó, akik különbözó nagyságú bankfiókok vagy takarékszövetkezetek élén állnak. Az ország más-más területén, eltérố gazdasági és pénzügyi környezetben, nagyon különbözố szerepeket töltenek be. Van közöttük területi igazgató, aki tucatnyi fiókot felügyel; 20 fôss bankfiók vezetôje és nagy fiókhálózattal rendelkezố, száznál több dolgozót foglalkoztató takarékszövetkezet ügyvezetố igazgatója.

\section{Vezetók és a vezetói pozícióba kerülés}

Kapcsolódva a BKE Szociológiai tanszékén folyó ,,Gazdasági elit” kutatáshoz, a takarékszövetkezetek és bankfiókok vezetôinek a véleményét is megkérdeztük arról, hogy a közgazdasági, jogi, múszaki szakismeretek, felsőfokú végzettség, jó összeköttetések, kapcsolatok, emberekkel való bánni tudás, nyelvismeret, munkás származás, párttagság, vállalkozói szellem, szerve- 
zési készség mennyire volt fontos a '80-as évek második felében a vezetốkiválasztásban, illetve ô maga mely tényezốket, milyen súllyal venné figyelembe.

A ,Gazdasági elit” kutatás során megkérdezett topmenedzserek véleménye szerint a '80-as évek második felében a vezetố pozíció elérésének legfontosabb kritériuma a , jó összeköttetések és kapcsolatok" volt. Ennek megítélésében egységesen nyilatkoztak a vezetốk, nem észlelhetổk különbségek sem életkor, sem nemek tekintetében. Ezt követte a párttagság mérlegelése és a felsőfokú végzettség figyelembe vétele. A vezetôk szaktudásának (közgazdasági és múszaki szakismereteinek) fontossága megelốzte az emberekkel való bánni tudás képességét. Ez utóbbi a vállalkozói szellemmel és a szervezési készséggel együtt közepesen fontos helyet foglalt el, a munkás származás pedig ekkorra már elvesztette jelentôségét. A bankfiókvezetốk körében végzett felmérés során kicsit eltérô értékekkel, de lényegében azonos eredmény született (6. táblázat).

\section{TÁBLÁZAT}

A vezetók véleménye a vezetók kiválasztásában érvényesült tényezókról*

(Managers' opinion on the requirements applied management selection)

\begin{tabular}{l|c|c|c|c}
\hline & 1991 & 1992 & 1991 & 1992 \\
\hline \multicolumn{1}{c|}{ Tényezók } & \multicolumn{2}{|c|}{ Mennyire volt fontos? } & \multicolumn{2}{c}{ Menyire kellene fontosnak lennie? } \\
\hline Jogi ismeret & 2,282 & 2,523 & 3,674 & 3,908 \\
\hline Közgazdasági szakismeret & 3,357 & 3,186 & 4,500 & 4,604 \\
\hline Jó összeköttetések, kapcsolatok & 4,307 & 4,386 & 3,085 & 3,292 \\
\hline Tudjon bánni az emberekkel & 3,163 & 3,125 & 4,252 & 4,477 \\
\hline Párttagság & 3,800 & 3,944 & 1,305 & 1,167 \\
\hline Mûszzaki szakismeret & 3,264 & 2,595 & 3,737 & 3,329 \\
\hline Felsófokú végzettség & 3,738 & 3,431 & 4,409 & 4,640 \\
\hline Munkás származás & 2,314 & - & 1,234 & - \\
\hline Vállalkozói szellem & 2,745 & 2,453 & 4,783 & 4,689 \\
\hline Szervezési készség & 3,216 & 3,011 & 4,691 & 4,800 \\
\hline Nyelvtudás & 2,277 & 1,559 & 4,519 & 4,337 \\
\hline
\end{tabular}

*A vezetớk egy-egy tényezó fontosságát 1-tổ 5-ig (nem fontostól nagyon fontosig) pontozhatták.

Forrás: 1991-es adatok a ,Gazdasági elit” kutatás eredményei.

1992-es adatok a kérdốíves felmérésból származnak.

A vezetốkiválasztás mechanizmusának nem elhanyagolható jellemzôje volt, hogy nem, vagy csak kevéssé létezett tudatos karrierépítés, mivel a vezetô pozíciókba kerülés esetleges volt, az ismeretségen, a döntést hozók szimpátiáján, a megüresedéseken, a pozíciók véletlenszerú elosztásán vagy a politikai széljárásnak megfelelố újraelosztásán múlott (Bóday 1958). Ez nem jelentette azt, hogy bárki bekerülhetett a vezetốk közé, mindössze annyit, hogy bizonyos képes- 
ségekkel rendelkezôk és formális kritériumoknak megfelelốk körén belül a válogatás esetleges volt.

A vezetốkiválasztásban érvényesült kritériumokhoz képest a topmenedzserek más jellemzổket vennének figyelembe. Nagyon fontosnak tekintenék a vállakozói szellemet, a szervezési készséget, a közgazdasági szakismereteket és a nyelvtudást. Ezek mellett fontos tényezóként vennék figyelembe a felsơfokú végzettséget és az emberekkel való bánni tudást. Leginkább a párttagság, a kapcsolatok és a munkásszármazás értékelổdött le, bár a vezetỡvé válásban a kapcsolatok fontosságát közepesre értékelik (6. táblázat).

Ebben a kérdésben is hasonlóképp nyilatkoztak a takarékszövetkezeti és bankfiókvezetôk is: lẹgfontosabbnak a szervezési készséget, a vállalkozói szellemet, a felsơfokú végzettséget és a közgazdasági szakismereteket tekintenék. Jelentốsen felértékelổdne a nyelvtudás és az emberekkel való bánni tudás is.

A kapcsolatok jelentôsségének megítélésében kettổs szempont érvényesült. A korábbi állapotokra vonatkoztatva a vezetôk gyakran úgy értelmezték, hogy a személyes ismeretségre a pozíció elérése miatt volt szükség, a jelenlegi helyzetben viszont az üzletmenet sikere érdekében kell a vezetônek széleskörứ ismeretséggel rendelkeznie. Sem a kérdésfeltevésben, sem a válaszokat nézve nem választható szét e két szempont. Így a megkérdezettek aszerint adtak alacsonyabb vagy magasabb pontot, hogy az elmúlt vagy a jelenlegi viszonyokra vonatkoztatták-e a kapcsolatok jelentôségét.

A tapasztalatok tehát azt mutatják, hogy a vezetók munkatársaik kiválasztásában a '80-as évek második felében is jellemzó formális kritériumok helyett a vezetối munkához szükséges képességek és tudás birtoklására helyeznék a hangsúlyt.

A kérdôíves vizsgálat során 25 nớt és 32 férfit kérdeztünk meg arról, hogy milyen körülmények között nyerte el jelenlegi állását, ebben milyen képességek voltak fontosak. Ezen túl a pozíció elvállalásának oka felól is tudakozódtunk. A kérdések nyitottak voltak, minden kérdésre korlátlan számú választ lehetett adni.

A legtöbb vezetố pályázat vagy kiválasztás útján, a takarékszövetkezetek esetében megválasztás révén került pozícióba. Emellett gyakran említették, hogy nem volt más megfelelổ képzettségû̉ vagy alkalmas ember az állás betöltésére. A beszélgetések megerốsítették, hogy még mindig szükség van kapcsolatokra a vezetỏi állás elérése érdekében. Ezt bizonyítja, hogy a bankfiókvezetối állások pályázati úton való betöltése ellenére magas a kiválasztottak aránya, azzaz a pályázat kírása formalitás volt csupán. (Abban egyetértenek a vezetôk, hogy sokkal kevésbé kellene az ismerôsökre támaszkodni, növelni kellene a szakmai szempontok súlyát a döntések meghozatalában.)

A vezetôii állás betöltéséhez szükséges jellemzók közül legtöbbször a szakképzettséget és a gyakorlatot említették, ami a szakmai szempontok érvényesülésére enged következtetni. Fontosnak tekintették a helyi viszonyok ismeretét és azt is, hogy ismerjék ốket. A megkérdezettek szerint lényeges, hogy az állás betöltésénél felmerüljön az illetổ neve, és az is, hogy a kiválasztntt vezetố rendelkezzék a problémák megoldásához és az eredményes mũködéshez szükséges kapcsolatokkal. A személyes tulajdonságok közül kiemelték a szervezókészséget, a kapcsolatteremtố és döntési képességet, a vállakozó hajlamot. A vezetốk saját kiválasztásuk során mérlegelt tényezốkre vonatkozó válaszaiból az derült ki, hogy esetükben a ténylegesen érvényesített kỏvetelmények és a vezetốkiválasztásban általuk kívánatosnak tartott követelmények lényegében azonosak. 
A legtöbben kihívásnak tekintették az állást, ki akarták próbálni képességeiket, bizonyítani rátermettségüket. Különösen a nốk számára volt fontos a szakma szeretete, a hivatástudat, és gyakori szempontként szerepelt a munka változatossága is. Nem kaptak különösebb hangsúlyt az anyagi elổnyök, amely - figyelembe véve, hogy a legjobban fizetố foglalkozás kicsit meglepó. Az önállóság és felelôsség iránti vágy sem volt túl erổs törekvés a vezetốkben.

Kevesen vallották, hogy az érvényesülés, a karrier lehetốsége vonzotta ốket a pályához; e válaszokban valószínũleg szerepet játszott a , karrierista” jelzô pejoratív értelme. A vezetốk többsége számára ugyanis az elốbbrejutás a pályafutás természetes velejárójaként fogalmazódott meg, de a törekvésüket az elốbbrejutásra nem szívesen mondták ki, illetven nem nevezik karriernek.

A válaszokból kiderült, hogy a vezetốk zöme aktív félként viszonyult az álláslehetôséghez, céljaik megvalósulási lehetôségét látták benne. Ez a tudatos karrierépítés csíráit mutatja, amelyre a menedzsereknek az elmúlt években csak kevés lehetôsége volt a vezetốk kiválasztásában érvényesülố szempontok miatt.

\section{A vezetók életkora}

A mintánkban a vezetốk átlagos életkora 44,6 év. A nổké alacsonyabb $(44,0)$, mint a férfiaké $(47,3)$, a bankfiókok vezetôii $(43,6)$ fiatalabbak a takarékszövetkezetek elnökeinél $(48,8)$. A legidôsebbek a takarékszövetkezeti férfi vezetôk, a legfiatalabbak a bankfiókot vezetổ nốk.

Az átlagéletkor nagysága nem különbözik jelentôsen a ,,Gazdasági elit" kutatás eredményétởl (Nagy 1992), és a kor nemek szerinti eltérései is megfelelnek az általános tapasztalatnak. A kétféle pénzintézet közötti különbség visszavezethetổ a két intézmény eltérô helyzetére. A takarékszövetkezetek régóta, nagy hagyományokkal, lokális szinten múködnek, és ilyen intézményben a vezetổ pozíció viszonylag stabil állást jelentett, ezért vezetổik általában régóta betöltik e pozíciót. A fiatal kereskedelmi bankok szervezôdổ hálózatában nincsenek meg ezek a feltételek. Feltételezhetjük azt is, hogy egyrészt a kereskedelmi bankfiókokban teremtôdött új helyzethez a fiatalabb generáció rugalmasabban tud alkalmazkodni, másrészt az idôsebb generáció tagjainak pályafutásuk során alkalmuk volt olyan elổnyökre szert tenniük (szakmai elismertség, kedvezô jövedelmi viszonyok, magas pozíció stb.), amelyekkel egy induló bankfíók kevéssé tud versenyezni. A pénzintézeti törvényben elôírt felsơfokú végzettség és a kereskedelmi bankok újszerú tevékenysége által támasztott fokozottabb igények némiképp magyarázatul szolgálhatnak arra, hogy a takarékszövetkezetek idôsebb, kevésbé képzett és a pályafutásuk során sokféle elônyt felhalmozott vezetổi miért nem kapcsolódtak be a bankok expanziójába.

A vezetôk iskolai végzettsége

A takarékszövetkezeti vezetốk iskolázottsági szintje - ez sem meglepó - alacsonyabb, mint a bankfiókvezetớké, és mindkét intézménytípusban a nók rendelkeznek alacsonyabb képzettségi színvonallal (7. táblázat). 


\section{TÁBLÁZAT}

Bankfiók- és takarékszövetkezeti vezetôk iskolai végzettség szerinti megoszlása (\%) (Education of managers' in branch banks and savings banks by gender)

\begin{tabular}{|c|c|c|c|c|c|c|c|c|}
\hline \multirow{2}{*}{$\begin{array}{l}\text { Legmagasabb } \\
\text { iskola végzettség }\end{array}$} & \multicolumn{3}{|c|}{$\begin{array}{c}\text { TAKARÉK- } \\
\text { SZÖVETKEZET }\end{array}$} & \multicolumn{3}{|c|}{ BANKFIÓK } & \multirow{2}{*}{ NÓ } & \multirow{2}{*}{ FÉRF } \\
\hline & Nố & Férfi & $\begin{array}{l}\text { Nóḱ } \\
\text { aránya }\end{array}$ & Nố & Férfi & $\begin{array}{l}\text { Nớk } \\
\text { aránya }\end{array}$ & & \\
\hline Középiskola & 52,4 & 33,3 & 61,1 & 15,2 & 0,0 & 100,0 & 29,6 & 13,0 \\
\hline Mérlegképes könyvelối & 23,8 & 28,6 & 45,5 & 3,0 & 0,0 & 100,0 & 11,1 & 11,1 \\
\hline Fổiskola & 14,3 & 9,5 & 60,0 & 30,3 & 24,2 & 55,6 & 24,1 & 18,5 \\
\hline Egyetem & 0,0 & 19,0 & 0,0 & 24,2 & 39,4 & 38,1 & 14,8 & 31,5 \\
\hline Több diploma & 9,5 & 4,8 & 66,7 & 24,2 & 36,4 & 40,0 & 18,5 & 24,1 \\
\hline Jelenleg tanul (föisk.) & 0,0 & 4,8 & 0,0 & 3,0 & 0,0 & 100,0 & 1,9 & 1,9 \\
\hline
\end{tabular}

Forrás: Kérdőives felmérés, 1992.

A takarékszövetkezeti vezetốk $40 \%$-ának középiskolai végzettsége van, 26\%-uk mondhat magáénak felsốfokú szakmai végzettséget, egyetemi diplomával csak minden negyedik rendelkezik. A nốk körében ezek az arányok valamivel rosszabbak: több mint felének csak középiskolài végzettsége, valamivel kevesebb mint negyedének mérlegképes könyvelổi vizsgája van. Felsőfokú végzettséggel hasonlóképp csak a takarékszövetkezeti vezetố nốk negyede rendelkezik. Valószínứnek látszik, hogy a takarékszövetkezetek városokba, majd megyeszékhelyekre településének engedélyezése óta több felsôfokú végzettségũ került be a vezetésbe. Ezt bizonyítja, hogy a diplomás takarékszövetkezeti vezetốk mindegyike városban volt vezetố vagy városból járt a községekbe.

A vizsgált körben a bankfiókok vezetőinek $9 \%$-a nem rendelkezik felsởfokú végzettséggel, egy fở jelenleg fớiskolán tanul. Valamennyien nổk. Közülük hárman nagy szakmai tapasztalattal rendelkeznek, és az idôsebb korosztályhoz tartoznak. A két fiatal nổ egyike IBUSZ-iroda vezetőjjeként csöppent bele a bankszakmába, míg a másik egy radikális foglalkozás-váltással vált bankfiókvezetốvé egy kisvárosban. A nổi vezetốk $80 \%$-a felsôfokú végzettségư. Ebbổl $30 \%$-nak fôiskolai végzettsége van, minden negyedik rendelkezik egyetemi diplomával, és ugyanennyien szereztek több diplomát. A férfiak iskolai végzettségi szintje magasabb, valamennyien felső́fokú végzettségúek. A legtöbben (39,4\%) egyetemi diplomával bírnak, de a tôbbdiplomások száma sem marad el lényegesen ettól $(36,4 \%)$.

A bankszféra egészére vonatkozó adatoknál mintánk lényegesen kedvezốbb képet mutat. Ez valószínúleg annak köszönhetổ, hogy a szerveződoo fiókhálózatok élére az egyetemekról és fơiskolákról néhány éve kikerültek pályázhattak sikerrel, mivel már rendelkeztek valamennyi gyakorlati idôvel és a pénzintézeti törvény által elôirt felsőfokú végzettséggel.

A vezetôk felsőfokú képzettségüket 54,5\%-ban nappali, 14,3\%-ban esti, 31,2\%-ban levelezô tagozaton szerezték meg. A nốk a férfiaknál kisebb arányban tanultak nappali tagozaton. A 
nốk 44\%-a nappali, $21 \%$-a esti és $35 \%$-a levelezổ tagozaton szerezte meg a diplomáját, míg a férfiak $63 \%$-a nappali, $9 \%$-a esti, $28 \%$-a levelezô tagozaton végezte felsôfokú tanulmányait.

Az iskolai végzettség megszerzésének módja nốk esetében szorosan összefügg a gyermekszülés idốpontjával. Azok a nốk, akik 21 éves koruk elốtt szülték meg elsổ gyermeküket, a felsôfokú végzettséget nem nappali tagozaton szerezték meg. A gyermeknevelés és a tanulás összeegyeztetése nagy erôfeszítéseket követel a családban. Akadt olyan házaspár, aki ezt külsố segítség nélkül oldotta meg, ez azonban nem tipikus. Az esetek többségében nem a házastárs, hanem a szülớk segítettek, részben a háztartási, részben a szülởi teendốk átvállalásával. A nappali tagozaton tanult nốk elsố gyermeküket többnyire a végzettség megszerzése után szülték.

\section{A vezetók pályafutása}

A vizsgált körben a vezetốk pályafutása általában a 29. életév környékén kezdổdött. A nốké valamivel korábban, mint a férfiaké, a bankfiókok vezetốinél elốbb, mint a takarékszövetkezeti vezetốknél, de lényeges különbség nem tapasztalható sem a nemek, sem a két intézménytípus között. Az elsố vezetô pozícióba kerülés idổpontjának alakulása ellentmond az elốzô évi felmérés eredményeinek. Akkor azt tapasztalták, hogy a nốk valamivel késốbb kezdik meg vezetối pályafutásukat, feltehetốen a gyermekszülés miatti kiesés következtében (Nagy 1992). Jelenlegi pozíciójukban a takarékszövetkezeti vezetốk régóta, a bankfiókvezetốk természetesen néhány éve tartózkodnak.

A vezetớk pályafutásának tipizálásával kapcsolatban számos probléma merült fel. Az elemzés alapjául a Wasilewski-féle (1986) csoportosítás (műszaki, adminisztratív, menedzseri, szakértôi és politikai, valamint az ezekbốl alkotható kevert típusok) szolgált azzal a különbséggel, hogy az egyes csoportokba történố besorolás kritériumai nem mindenütt felelnek meg Wasilewski verziójának. A tipizálásban az egész pályafutás formális kritériumai részt vettek, de számos olyan további jellegzetesség is felfedezhetô, melyek nem elhanyagolhatók az elemzés során.

Elsổ megközelítésben külön kell választani a belsô és külsô pályafutásokat. Ennek a megkülönböztetésnek azért van jelentôsége, mert Magyarországon nem volt bankárképzés, csak az MNB-n belül.

A pályafutások a fenti kiegészítésekkel együtt a következố kategóriákba sorolhatók:

A ,,belsó adminisztratív" pályafutású vezetốk közé azok kerültek, akik a hivatali ranglétra fokait a banki szférán belül járták végig. Ebbe a csoportba soroltuk azokat is, akik a jelenlegi állásuk elớtt másutt dolgoztak, de korábban jelentôs banki vagy takarékszövetkezeti gyakorlatot szereztek.

A , ,külsốadminisztratív" pályafutásúak kategóriájába azok tartoznak, akik nem a banki szférában járták végig a vezetési hierarchia fokait, hanem vezetốként kerültek be a bankszakmába.

A , külsó-belsó adminisztratív" pályafutásúak azok, akik részben a banki szektorban, részben azon kívül járták végig a ,,szamárlétrát".

A , ,müszaki-adminisztratív" kategóriába azok kerültek, akik a pályafutásukat múszaki vonalon kezdték meg, majd adminisztratív körökben folytatták. (Ez abban különbözik Wasilewski álláspontjától, hogy nem szükséges hozzá mũszaki vezetôi beosztásokon elổrejutni, a besorolás kritériuma az volt, hogy a pályafutás legalább harmadát múszaki beosztásban kellett eltölteni.) 
Az , ugrásos" karrier azt jelenti, hogy a vezetố pályája során valamikor vagy több hierarchikus lépcsổt kihagyva lépett elốre, vagy egy lényegesen magasabb társadalmi presztízsư állásba került.

A ,,szakértói" pálya azoké, akik pályafutásuk legalább $80 \%$-ában a hierarchikus elốrejutási pályákon kívül tevékenykedtek, majd egy fordulattal bankfiók illetve takarékszövetkezet vezetởivé váltak.

A ,,menedzser" típusú pályát azok futottak be, akik vezetó pozícióban kezdtek és azon belül mozogtak, vagy azok, akik a pályafutás során legfeljebb két évig - ez a gyakornoki idốt jelenti $\rightarrow$ nem voltak vezetốk.

A , politikai-szakmai" "pálya esetén a politikai állás betöltése mellett valamilyen szakmai karriert is befutott a vezetố, de a politikai állás késốbb jobb helyzetbe juttatta. Néhány vezetố pályafutását több kategóriába is be lehetett volna sorolni, illetve akadt olyan is, melyet nem fed le teljes mértékben a csoportosítás, illetve olyan jellemzőkkel rendelkezik, amelyek bizonytalanná teszik a kategorizálását.

\section{TÁBLÁZAT}

A vezetók pályafutásának típusai pénzintézetenként és nemenként (Career types of bank managers by gender in different types of banks)

\begin{tabular}{l|c|c|c|c|c}
\hline \multicolumn{1}{|c|}{ Pályafutás típusa } & Takarékszövetkezet & Bankfiók & Nó & Férfi & Együtt \\
\hline Külsố adminisztratív & 10 & 24 & 16 & 18 & 34 \\
\hline Belsố adminisztratív & 10 & 21 & 22 & 9 & 31 \\
\hline Ugrásos & 11 & 13 & 10 & 14 & 24 \\
\hline Menedzser & 4 & 2 & 1 & 5 & 6 \\
\hline Múszaki-adminisztratív & 1 & 3 & & 4 & 4 \\
\hline Külsố-belsố adminisztratív & 3 & 1 & 4 & & 4 \\
\hline Szakértối & 2 & 1 & 1 & 2 & 3 \\
\hline Politikai-szakmai & 1 & 1 & & 2 & 2 \\
\hline
\end{tabular}

Forrás: Kérdớives felmérés, 1993.

A vezetốk zöme a terület jellegébốl következôen hagyományos adminisztratív pályát járt be (8. táblázat). A bankfiók és takarékszövetkezeti vezetốk $2 / 3$-a végigjárta a hivatali hierarchiát; a teljes hierarchiát ,,belül" a vezetốk $29 \%$-a, a pénzintézeti szférán kívül $35 \%$-a járta végig, $4 \%$ kezdte meg a gazdaság más területén, de pénzintézetben fejezte be. Magas az , ugrásos" pályafutásúak aránya. Összesen 8 ugrás történt a banki szférán kívül, két esetben a pénzintézeti hierarchián belül, a többi esetben a jelenlegi beosztásba kerülés jelentette az ugrást. Mintánkban más módon elenyészốen kevesen kerültek vezetổ pozícióba.

A vezetớk pályafutásának jellegében a takarékszövetkezeteket és bankfiókokat tekintve nincsenek számottevổ különbségek. Mégis említésre méltó, hogy a takarékszövetkezeti vezetốk 
kisebb arányban választódtak ki a takaréksszövetkezet dolgozói közül, és több az ugrás a vezetổk karrierjében.

Jelentốsek a nemek közötti különbségek. A legnagyobb eltérés, hogy a nốk lényegesen nagyobb arányban belsố neveltetésũek, azaz inkább a pénzintézeti szférán belül járták végig a hierarchiát. Ha ehhez hozzáadjuk azokat, akik a ,,szamárlétra" utolsó néhány fokát a pénzintézeti szektorban tötötték be, akkor azt látjuk, hogy a nốk mintegy felének (48\%) a pénzügyi szférán belül kellett igazolnia rátermettségét, más oldalról a pálya elnôiesedettsége miatt sokan már belül bizonyítottak, és ennek okán kerülhettek vezetô pozícióba. Ezzel szemben a férfiaknak csak $17 \%$-a rendelkezett pénzintézeti múlttal, ami azt jelenti, hogy férfiak a takarékszövetkezetekhez szinte kizárólag vezetổ pozícióba mentek; a bankokhoz pedig a fentebb ismertetett okok miatt csak az utóbbi idôben vonzódnak.

A pénzintézeti szférán kívül a nốk $30 \%$-a, a férfiak $41 \%$-a futott be adminisztratív, illetve mû́szaki-adminisztratív pályát. Összességében a nốk $78 \%$-a, a férfiak $57 \%$-a járta végig a vezetési hierarchia lépcsôfokait.

Mindezzel összefüggésben a nốk pályafutása során kevesebb az ugrás. A nốk által végrehajtott ugrások fele a pénzintézeti szférán kívül történt, a másik fele a pénzintézeti állásba kerülést jelentette. A férfiak ugrásainak zöme a jelenlegi állásba lépést jelenti (14-ből 11 eset, ebbốl egy történt a banki hierarchián belül), s ez kétszer annyi, mint amit a nốk elértek. A takarékszövetkezetek esetében a férfi vezetốk harmada jutott ily módon vezetôi székbe. Itt az ugrások a '70-es évek elején és nem adminisztratív pályákról történtek. A férfiak gyakran több fokot is ugrottak elôre a hierarchiában. A bankfiókok férfi vezetôinek ötöde hajtott végre ugrást, ami arra utal, hogy a régebben nem túlzottan kedvelt, de újabban ígéretes területre sikerrel startoltak a férfiak. Itt a korábban leírt konjunkturális kontraszelekciós mechanizmus múködését ismerhetjük fel.

A vezetốk más típusú karrierje nem gyakori. Mintánkban kevés számban fordult eló a menedzseri pálya, amely inkább jellemzổ a férfi, mint a nô vezetốkre. Ennek vélhetốen az az oka, hogy a nốket pályakezdéskor elvétve helyezik azonnal vezetô pozícióba a várható gyermekszülés és az azzal járó munkamegszakítás miatt. A fiatal és egyetemi végzettségũek között fordult elố, hogy nem menedzseri állásban kezdtek, a ranglétrát nagyon rövid idôn belül (1-1,5 év) futották be. Ez valószínúleg a szakemberhiány miatt következhetett be.

Mintánkban nem volt jellemzổ a politikai szerepvállalás sem. Mindössze két férfi vállalt politikai funkciót, ezelốtt azonban már mindketten befutottak valamilyen mûszaki-adminisztratív karriert. A politikai múlt nem volt jó ajánlólevél a bankfiókok élén, de a széles ismeretségi kör a pályafutásukat pozitívan befolyásolta.

A vezetốk pályafutására nem volt jellemzố a hierarchián való visszacsúszás. Előfordult, hogy valakit komoly hiba miatt átmenetileg , talonba tettek", hogy késốbb ismét vezetô pozíciót töltsön be. Gyakoribb volt azonban, hogy a vezetô más pályán kifutotta magát, nem volt már elổrelépési lehetôsége, ezért átváltott a pénzügyi vonalra, de ott alacsonyabb státuszban kezdett, mint elôzzổ munkahelyén.

Sajátos momentum 9 vezetố pályáján, hogy hosszabb ideig dolgoztak érdekképviseleti szerveknél. Ez csupán egyikük esetében járult hozzá a gyorsabb karrierhez, de úgy tûnik, korábbi pozíciójuk valamennyiüknél segítette a vezetố pozíció elérését. A TESZÖV-nél, illetve MESZÖV-nél eltöltött idố arra volt jó, hogy ezek az emberek legalább egy, de inkább több me- 
gyében ismeretségre, fontos kapcsolatokra tettek szert; az állás betöltése ismeretek szerzésére és személyes kapcsolatok, befolyások kiépítésére adott alkalmat. Ez hozzájárult ismertté válásukhoz, és elfogadottá vál(hat)tak azon intézmények körében, melyek most a bankok potenciális ügy felei. A megkérdezett vezetốk szerint mindezen tényezốk fontosak voltak vezetối pozícióba kerülésüknél.

A vezetốk pályafutását elemezve összefüggés fedezhetô fel az iskolai végzettség megszerzésének módja és a karrierpálya típusa között, de a karrier mintáját a nốk esetében a gyermekszülés ideje átrajzolja. Példaként erre azok az esetek hozhatók, melyekben az , ugrások” mögött levelezổ vagy esti képzés formájában megszerzett magasabb, többnyire felsôfokú végzettség állt. , ,Menedzser" típusú karriert csak egyetemi végzettségúek futottak be.

\section{$A$ vezetók bére és bérkülönbségei}

A kérdés behatóbb vizsgálatát több probléma is akadályozza. Az elsô, hogy a személyi jövedelemadó bevezetése óta maga a kérdés indiszkrétnek minôsül, a bérre vonatkozó információ egyre több helyen a hivatali titok kategóriájába tartozik. Ez azonban nem akadályozta meg a vezetôket abban, hogy a kérdésre válaszoljanak.

A következố problémára a vezetớk megkeresése során derült fény. A kérdôíven szerepló , havi nettó jövedelem" rovatba eltérô tartalmú adatokat írtak be kitöltôiik. Volt, aki a havi nettó jơvedelmét írta be, volt, aki a havi nettó bérét. A kettố között olyan lényeges különbség lehet, ami már megkérdôjelezi az adatok értelmezhetôségét. Ugyanis a vezetốk eltérô mértékú, külơnféle paraméterektôl függó jutalékot kaptak, ennek mértéke saját bevallásuk szerint az éves bér 30\%-ától 150\%-áig terjedt. A rendelkezésre álló adatokból nem deríthetố ki egyértelmúen, hogy ki, mely összeget írta be, pusztán sejteni lehet, hogy bérrốl vagy jövedelemrốl van-e szó. Ezért az átlagbérek nagysága valószínüleg erơsen függ attól, hogy az adatszolgáltatók hogyan értelmezték a kérdést, és a kis minta miatt nem lehet megbecsülni a torzítás mértékét, így jelentớs fenntartásokkal kell kezelni a kapott mutatók értékét. ${ }^{5}$ A kérdốíven nem kérdeztünk rá a jelentốs egyéb kiegészítố jövedelmekre (ruhapénz, étkezési hozzájárulás, költségtérítés, albérleti támogatás, üdülési, utazási kedvezmények, tanulási és sportolási lehetôségek stb.), melyeknek mértéke változó, ebben a vezetési kategóriában az éves bér 10-30\%-át is elérheti.

A bérek nagyságát elsôsorban az intézmény típusa és nagysága befolyásolja. Azaz minél nagyobb a takarékszövetkezet, bankfiók, annál nagyobb javadalmazásra van lehetôség, és a bankok általában jobban fizetnek, mint a takarékszövetkezetek. A pénzintézetek eredményessége és mérete függ a település nagyságától és a gazdasági környezet kondíciójától is. A környezeti tênyezốk, adottságok mellett a béreket befolyásolják a vezetố személyének jellemzới is, leginkább a kor, a szakmai tapasztalatok, az iskolai végzettség szerint alakulnak a bérek (9. táblázat). 


\section{TÁBLÁZAT}

Takarékszövetkezeti és bankfiókvezetók bére (Ft) és bérarányai (\%)

(Salaries (Fts) and wage indices (\%) of managers in savings banks and branch banks))

\begin{tabular}{l|c|c|c|c}
\hline & Nó & Férfi & Együtt & Nó/Férfi \\
\hline Takarékszövetkezet & 30342 & 31683 & 30996 & 95,8 \\
\hline Bankfiók, vidék & 35322 & 44214 & 40734 & 79,9 \\
\hline Bankfiók együtt & 40432 & 43964 & 41544 & 92,0 \\
\hline Együtt & 36108 & 39053 & 37929 & 92,5 \\
\hline \hline
\end{tabular}

A bankfiókok és takarékszövetkezeti vezetốk bére jelentôsen eltér. A takarékszövetkezeti vezetốk általában $25 \%$-kal kevesebbet keresnek, mint a bankfiókvezetốk. Ez a különbség a férfiak között valamivel nagyobb, mint a nốk között. Figyelembe véve azt, hogy a bankfiókvezetốk általában városokban tevékenykednek, a takarékszövetkezeti vezetốk pedig falvakban, az itt talált differencia nem haladja meg a falusi és városi vezetốk bérkülönbségeinek szintjét.

$\mathrm{Az}$ összesített adatok szerint a nemenkénti eltérés alacsony, alcsoportonként azonban differenciáltabb képet kapunk. A takarékszövetkezeti vezetổ nók bére $4 \%$-kal alacsonyabb a férfiakénál, ez a különbség elhanyagolható mértékû. Vidéken a bankfiókok vezetőinek bérei között $20 \%$-os eltérés mutatható ki, ami az elemzés korlátainak a figyelembevételével is a differenciák létét igazolja. ${ }^{6}$ A budapesti adatokkal összesítve ez a különbség 8\%-ra csökken. Ennek egy részét igazolja a fôvvárosi és a vidéki városok fizetései közötti eltérés. Másrészt adottság, hogy Budapesten a kereskedelmi bankok nemrég kezdték meg fiókhálózatuk kiépítését, domináns mértékben van jelen az OTP. Az adatok forrásául szolgáló Almanachban a 29 budapesti OTP fiók vezetổje közül 20 nố, akik régóta, képzett szakemberekként végzik munkájukat, és béreik is ennek megfelelőek. Mintánkba így két szélsôség került be: egyik oldalon az OTP több évtizedes tapasztalatokkal rendelkezõ kerületi igazgatói, a másik oldalon nemrég nyílt kereskedelmi bankfiókok fiatal vezetỏi. ${ }^{7}$

A felmérés meglehetôsen bizonytalan adataiból annyi derül ki bizonyosan, hogy a bérek elsósorban a vezetett intézmény nagysága, a település típusa, a vezetổ kora, szakmai tapasztalatai és iskolai végzettsége szerint alakulnak. A nemenkénti bérkülönbségek mértéke és okai ebból a felmérésbốl egyértelmủen nem határozhatók meg. A ,,Gazdasági elit" kutatásban eredményül kapott nagy mértékư nemenkénti bérkülönbség a bankok adatszolgáltatása és tapasztalataink szerint leginkább a vezetési hierarchiában elfoglalt alacsonyabb pozíció következtében alakulhat ki, mivel e hierarchián belül a bérek nagyságrendekkel eltérnek egymástól. 


\section{A vezetók családi háttere}

A kétféle pénzintézetnél lényeges eltérések nem tapasztalhatók a vezetốk családi állapot szerinti megoszlásában. Nemenként azonban már jelentốs különbségeket mutatnak az adatok.

A vezetổ nớk között az egyedülállók aránya több mint háromszor nagyobb, mint a férfi veze1ốk között, másként: a házasok aránya a férfi vezetốk között lényegesen magasabb (10. táblázat). A megfelelổ korú népességhez viszonyítva a nốk esetében lényeges különbség az elváltak és a hajadonok tekintetében van: az elváltak aránya másfélszerese az országos átlagnak. A férfi vezetốk között mind a vezetổ nốkhöz, mind a népességhez viszonyítva magasabb a házasok és alacsonyabb az elváltak aránya. Ez arra enged következtetni, hogy a nốk számára a karrier bizonytalanságot, a családi élet szempontjából hátrányokat hordoz, míg a férfiak esetében a vezetố pozícióhoz az átlagosnál stabilabb családi háttér társul.

\section{TÁBLÁZAT}

A családi állapot szerinti megoszlás a megfeleló korú népességben* és a mintában (\%)

(Marital status of total population and managers by gender)

\begin{tabular}{l|c|c|c|c}
\hline \multirow{2}{*}{} & \multicolumn{4}{c}{ Családi állapot } \\
\cline { 2 - 5 } & Hajadon, nốtlen & Házas & Özvegy & Elvált \\
\hline Népesség & 6,1 & 77,4 & 4,7 & 11,8 \\
\hline Minta & 1,9 & 75,9 & 5,6 & 16,7 \\
\hline \multicolumn{5}{|c}{ Férfiak } \\
\hline Népesség & 12,1 & 77,4 & 1,8 & 8,7 \\
\hline Minta & 1,9 & 92,6 & 0,0 & 5,6 \\
\hline
\end{tabular}

"Nók esetében a 25-55, férfiak esetében a 25-64 éves korosztály adatai szerepelnek. Ez megfelel a mintában szereplốk korösszetételének. Adatok forrása: 1990. évi népszámlálás 3. Összefoglaló adatok, 12-13. oldal.

Különbségek mutathatók ki a gyermekek számában is. A takarékszövetkezeti vezetốk gyermekeinek átlagos száma meghaladja a bankfiókvezetôkét, a nốk gyermekeinek száma pedig kevesebb, mint a férfiaké. ${ }^{8}$

\section{A vezetók házastársa}

A vezetó́k családi állapotának elemzéséból azt a következtetést vontuk le, hogy a vezetổ pozíció a férfiak számára az átlagosnál lényegesen nyugodtabb családi viszonyokkal jár, míg a nốk vezetổi ambíciói a családi kapcsolatokat fellazítják. Úgy véljük, hogy a házastársak iskolai végzettségének és foglalkozásának elemzése tovább finomítja az adatok értelmezését. 


\section{A házastársak iskolai végzettsége}

Az adatok az mutatják, hogy a házastársak iskolai végzettségi szintje némiképp alacsonyabb, mint maguké a vezetốké. A vezetốk $53 \%$-a a házastársával azonos, $43 \%$-a annál nagyobb, $4 \%$-a alacsonyabb iskolai végzettséggel rendelkezik. Nincs lényeges különbség a vezetốk között a feleségek, illetve a férjek iskolai végzettséghez való viszony alapján, azaz nagyjából ugyanannyian rendelkeznek azonos vagy magasabb iskolai végzettséggel. (Viszont csak vezetố nố rendelkezik a férjénél alacsonyabb szintũ bizonyítvánnyal, a férfi vezetôk és feleségeik között gyakoribb az azonos fokú végzettség.)

A két pénzintézeti típus között különbségek tapasztalhatók. A takarékszövetkezeti vezetốknek és házastársaiknak a képzettségi színvonala kiegyenlítettebb: a vezetốk 74\%-ánál megegyezik, a nốk körében azonban gyakoribb a magasabb iskolai végzettség. A bankfiókvezetốknél egyöntetûbb a kép. Mind a nốk, mind a férfiak fele a házastársánál magasabb iskolai végzettséggel rendelkezik.

\section{A házastársak foglalkozása}

A vezetốk házastársainak $41 \%$-a vezetố, $18 \%$-a beosztott diplomás, $14 \%$-a ügyviteli alkalmazott. A legtöbb feleség ügyviteli alkalmazott, beosztott diplomás vagy középvezetô. A feleségek között a vezetốk aránya $32 \%{ }^{9}$ A két pénzintézetnél eltérỡ a feleségek foglalkozási szerkezete. A takarékszövetkezeti vezetốk feleségei leginkább ügyviteli alkalmazottak (32\%). Az alsó-, közép- és felsôvezetốk aránya együtt $42 \%$, közülük a legtöbben középvezetôk. A bankfiókvezetô feleségek leginkább diplomás szellemiek ( $32 \%)$, ügyviteli alkalmazottak ( $21 \%$ ) vagy vezetốk (24\%).

A legtöbb férj vezetố (51\%) és szakmunkás (15\%), nincsenek közöttük adminisztrátorok és kevés a beosztott diplomások aránya is (10\%). A takarékszövetkezeti vezetók férjei közül $40 \%$ vezetố, 35\% szakmunkás. A szakmunkások aránya valószínüleg azért nagy, mert a férfiak számára a legjobban értékesíthetổ képzettség - különösen községekben - a szakmunkás vizsga volt (a férfi munkavállalók majdnem fele szakmunkás!). Mint ismeretes, szakmunkások társadalmi megbecsültsége és megfizetettsége vonzóvá tette a férfiak számára e pályát. Emellett az adminisztrátor feleség és a szakmunkás férj azonos társadalmi státuszok közötti házasságot jelentett. A bankfiókvezetố nốk férjei fốként vezetốk (58\%) és beosztott diplomás szellemiek, de magas - bár nem a munkanélküléségi rátához képest - az almintában szereplố munkanélküliek száma is.

Azt mondhatjuk, hogy a takarékszövetkezeti vezetốk 40\%-a, a bankfiókvezetổ nốk $58 \%$-a, a bankfiókvezetổ férfiak $26 \%$-a szimmetrikus családban él, ahol a házastárs is vezetổ. Mivel a házaspárok közül mindössze egy alkalmaz fizetett segitốt, és kisgyermek mellett is mindössze egy alkalmazott fizetett segítốt, a családokon belül kellett megoldani a házastársi munkák ellátását és a gyermekneveléssel kapcsolatos feladatokat.

A férfiak számára kedvezô hátteret teremtett az elốrejutási lehetôségek nélküli pályán lévô ügyviteli alkalmazott feleség, vagy átmenetileg gyes-en vagy gyed-en lévổ anyuka, mivel általában elfogadták és támogatták a férj karriertörekvéseit.

A beosztott diplomás feleségek közül négy esetben várható, hogy a késôbbiekben valamilyen karriert bontakoztatnak ki, mivel még pályájuk elején tartanak. Egyikük tudományos tevékeny- 
séget folytat, és már elért bizonyos eredményeket. A többi diplomás feleség számára csak jelentốs és gyors fordulat hozhat karrierjében továbblépést, mivel az idôsebb generációhoz tartoznak vagy/és olyan pályákon vannak, ahol nincs elổrejutási lehetốség. Ez azt jelzi, hogy a diplomások közül is többen a férj karrierjét támogatták, illetve támogatják.

A nốk számára nem adatott meg a férfiakéhoz hasonló támogató háttér. A szakmunkás férjek társadalmi közegében a háztartási munka nem tipikusan tartozik a férj feladatai közé, ezért csak kivételes esetben jelentett támaszt a nốk számára pályafutásuk során. Kedvezó lehetôségeket jelenthetett volna magában a vállalkozó férj, aki a magasabb jövedelem révén mentesíthette volna a feleségét a terhek alól, de ez csak egyetlen esetben történt meg. Az sem volt jellemzổ, hogy a vezetố férj által elért jövedelem teremtett volna kedvezốbb lehetốségeket a feleségek számára.

A nốk számára valódi segítséget a szülớk és nagyszülốk jelentettek, akik átvállalták a háztartási munkák egy részét, és a gyermeknevelés gondjait is megosztották velük. További hathatós \$egítséget a bölcsổdei és óvodai ellátástól várhattak.

A családi háttér adatainak elemzése összességében megerôsítette, hogy a nốk számára a tradicionálisan nagyobb családi kötöttségek miatt az érvényesülés és a karrier épitése nehezebb. Ezt mutatja az egyedülállók magas aránya és a kisebb gyermekszám is. A menedzserek pályafutása során mindenképpen szükség van olyan háttérre, ami mentesíti ốket a mindennapok reprođukciós terheinek legalább egy részétốl. A férfiak számára ez tradicionálisan adott, a nốknek azonban nem. A férjeikre csak kevesen számíthattak az erổs konzervatív társadalmi szerepek és a családi munkamegosztás miatt, de az anyák és a nagyszülốk segítsége növelte lehetốségeiket. Pozitív fejlemény, hogy a fiatalabb szimmetrikus családokban az egyenlốbb teherviselés, a családon belüli munkamegosztás változása irányába mutatnak a jelek, ami a nốk esélyeinek javulását eredményezheti.

\section{Jegyzetek}

| Pl.: Magyar Beruházási Bank: beruházások finanszírozása, késóbb építôipari cégek számlavezetése, finanszírozása, Magyar Külkereskedelmi Bank: a külkereskedelem fizetési forgalmának lebonyolítására stb.

Sajnos bankfiókvezetớk neve nem minden esetben szerepelt, ezért pontosan nem lehet meghatározni a nemek arányát, erre vonatkozó becslés az alapadatok extrapolálásával történt. Emellett az Almanach adatai is tartalmaznak torzításokat, mert az önkéntes adatszolgáltatás során a pénzintézetek különbözö mélységứ adatokat jelentettek meg magukról. Így az MHB nem közölte a vezetớk nevét, az OTP csak a budapesti kerületi és a megyei igazgatóságokat szerepeltette, míg a kezdô IBUSZ Bank valamennyi fiókja szerepelt.

Az 1990. évi népszámlálás adatai szerint Magyarországon a vezetố, irányító beosztásúak száma 391989 , ebbốl nô 132 197, azaz 33,72\%. Forrás: 1990. évi népszámlálási 3. Összefoglaló adatok, KSH, 1992. 90-91. o.

Pénzintézeti foglalkozásúak száma 1990-ben: 14 710, ebból 11412 nổ. A vezetớk száma: 3286, ebból 2241 nổ (68,2\%). A pénzintézeti foglalkozásúak között a vezetốk aránya: nốk: 19,6\%, férfiak 31,9\%. A felsôfokú végzettségúek aránya: nớk: $10,3 \%$, férfiak: $41,2 \%$. A felsőfokú végzettségúek között a nớk aránya 46,3\%. Adatok forrása: 1990 . évi népszámlálás 3. Összefoglaló adatok, 90-91. és 102-103. oldal.

További torzítást okozott volna, ha az IBUSZ Bank fiókvezetổinek bérét is számbavesszük, ớk ugyanis a havi irodavezetối járandóságuk felét kapják fizetségül a fiókvezetổi teendớk ellátásáért. Ez az állapot 1993-tól megszűnt.

A bérkülönbségek mértéke tehát akkora, hogy nem fér bele a becslés hibahatáraiba, azaz azt megállapíthatjuk, hogy vannak különbségek, de ezek mértékéról az adatok alapján nem lehet nyilatkozni.

A budapesti mintánkban a nem OTP-s kereskedelmi bankfiókok élén zömében fiatalok voltak. Ennek okát abban véljük felfedezni, hogy az idősebb fôvárosi felsớfokú végzettségúeknek pályafutásukból adódóan egy kezdó bankfiók vezetésénél jobb lehetớségeik is adódnak. Igy kettớs hatás érvényesül: a fiatal kereskedelmi bankvezetớk már koruknál fogva is kevesebb bért kapnak, mint idősebb OTP-s kollégáik. Ráadásul a budapesti mintában, kivéve közülük az IBUSZ Bank vezetơit, többségbe kerültek a nớk.

Átlagos gyermekszám: takarékszövetkezetek: 1,81, bankfiókok: 1,48, nớk: 1,50, férfiak: 1,73.

A vezetớk házastársai közül a vezetớ foglalkozásúak között a nớk aránya: felsố vezetở $22 \%$, középvezetớk $44 \%$, alsó vezetók $60 \%$. 


\section{Irodalom}

Barron, R. D.-Norris, G. M. (1976) Sexual Divisions and the Dual Labour Market, In: Allen, S.-Barker, D. L. (eds): Dependence and Exploitation in Work and Marriage, Longman, London.

Bóday P. (1985) Vállalati felsố-vezetổi életutak nemzetközi összehasonlításban, In: A gazdasági vezetés szociológiai problémái a tervgazdaságban c. múhelyvita 1985 . november $14-15$., Kézirat, Budapest.

Crompton, R. and Jones, G. (1984) White Collar Proletariat, The Macmillan Press Ltd, London.

Koncz K. (1987) Nớk a munkaerópiacon, KJK, Budapest.

Nagy B. (1992) Nók a gazdasági vezetésben, Kézirat, Budapest.

Wasilewski, I. (1986) Az igazgatók társadalmi-szakmai pályafutása Lengyelországban, In: Szociológiai Múhelytanulmányok 3, Budapest.

\section{WOMEN IN THE MANAGEMENT OF FINANCIAL BUSINESS}

\section{ZSUZSANNA BIHARI}

Since 1987 Hungary has been operating a two-level bank system. The formation of commercial banks has created a great need for experts in a formerly closed and highly respected, yet poorly remunerated profession. It is particular to Hungary, that due to the low incomes, men previously avoided this sector of business. The rise of prestige of this profession has contributed to the rise of prestige of people engaged in this profession as well. This is not an ordinary turn in the case of professions cultivated primarily by women. Therefore, my investigation explores how women have been able to convert the gains obtained from an urgent need on the labor market into other sorts of advantage. I have drawn information, above all, from my own survey that I completed in the first half of 1992 . The survey questioned the managers of savings and commercial banks in the countryside. Due to the small size of my sample (108 questionnaires), I only raise some general questions and form initial hypotheses.

My results show that men have three times higher chance to get into the top managerial strata. As opposed to men, those women, who are nominated into higher positions, have usually climbed the hierarchy within this particular sector of business. As far as marital status is concerned, three times more women appear to be single than men among the managers. There are also less divorced among men than among women. One can draw the consequence that for women career conveys private uncertainties and disadvantage while men in top positions usually enjoy a stable family background. Women in the management usually do not have husbands in a highly paid profession; therefore, these families could not afford to hire domestic help. Moreover, in these families the division of household labour follows a conventional pattern. In contrast, men in the management of financial business are supported by their wives' larger shares in the household burdens. It is a promising experience that in the families of younger professionals a more just division of labour is in progress. 